\title{
Composition and Bioactivity of Essential Oil From the Leaves of Genipa americana Against the Coconut Mite Aceria guerreronis
}

\author{
Alex S. de Jesus ${ }^{1}$, Caroline R. Coelho ${ }^{1}$, Ighor C. Barreto ${ }^{1}$, José G. Sena Filho ${ }^{1}$, Paulo Cesar de L. Nogueira ${ }^{2}$, \\ Adenir V. Teodoro ${ }^{1} \&$ Ana Veruska C. da Silva ${ }^{1}$ \\ ${ }^{1}$ Empresa Brasileira de Pesquisa Agropecuária, Aracaju, Sergipe, Brazil \\ ${ }^{2}$ Laboratório de Pesquisa em Química Orgânica de Sergipe, Departamento de Química-CCET, Universidade \\ Federal de Sergipe, São Cristóvão, Sergipe, Brazil \\ Correspondence: Alex S. de Jesus, Empresa Brasileira de Pesquisa Agropecuária, Tabuleiros Costeiros, Av. \\ Beira Mar, 3250, 49025-040, Aracaju, Sergipe, Brazil. Tel: 55-79-4009-1362. E-mail: alexdadabio@gmail.com
}

Received: September 7, 2019

doi:10.5539/jas.v11n18p197
Accepted: October 11, $2019 \quad$ Online Published: November 15, 2019

URL: https://doi.org/10.5539/jas.v11n18p197

\begin{abstract}
Genipa americana L. has a diversity of secondary metabolites, including iridoids, phenolic compounds, and alkaloids. Pharmacological and biological properties have also been reported. This study has aimed to evaluate the chemical composition of the essential oil (EO) obtained from the leaves of G. americana and its bioactivity against Aceria guerreronis Keifer (Acari: Eriophyidae), a serious pest of coconut production areas worldwide. EO from the leaves was extracted and analyzed by Gas Chromatography-Mass Spectrometry and flame ionization detection (GC-MS/FID). For the bioassays, the adult coconut mites were subjected to increasing concentrations of EO. The analyses showed a predominance of sesquiterpenes, followed by monoterpenes, aldehydes, and fatty acids. The $\mathrm{EO}\left(\mathrm{LC}_{50}=0.41 \mathrm{mg} \mathrm{mL}^{-1} ; \mathrm{LC}_{90}=6.43 \mathrm{mg} \mathrm{mL}^{-1}\right)$ showed toxicity and repellent effects against the coconut mite. The tested $\mathrm{EO}$ has the potential to develop as a natural product, with acaricidal activities against $A$. guerreronis, in order to assist in the control of the coconut mite.
\end{abstract}

Keywords: Cocos nucifera, repellency, terpenes, toxicity

\section{Introduction}

Genipa americana L. (Rubiaceae) is widely distributed in tropical Central and South America and it presents an economic and environmental importance (Bailão et al., 2015; Sá et al., 2015). It possesses value for the recovery of degraded areas, composition in permanent preservation areas, and in agroforestry systems (Bailão et al., 2015; Sá et al., 2015). Satisfactory quantities of iridoids and tannins are found in the leaves and fruits, which display pharmacological actions (Silva et al., 2015). In addition, monoterpenoids, phenolic compounds, and steroids have been identified and isolated from the fruits of G. americana (Alves et al., 2017; Bentes \& Mercadante, 2014; Conceição et al., 2011; Ono et al., 2007). However, there is little research that has evaluated the chemical composition of the leaves, in fact, only two new iridoids from the leaves of the G. americana were recently reported (Alves et al., 2017).

Pests are a natural part of ecosystems, but they can be problematical in field crops and ornamental plants (Ajayi, Adedire, \& Lajide, 2012; Ebadollahi et al., 2017). Aceria guerreronis Keifer (Acari: Eriophyidae) is a species considered as a serious pest of coconut production areas worldwide, including the Americas, Africa, and some Asian countries. It occurs in high population levels in northeastern Brazil (Lawson-Balagbo et al., 2008; Souza et al., 2012). The coconut mite populations are found underneath the perianth and on the meristematic tissues of the coconut fruits (Navia et al., 2013; Lima et al., 2012; Melo et al., 2014). The mite causes chloroses that are triangular in shape, and as they develop, they become brown, causing superficial and longitudinal cracks of a dark brown color to fruits (Moreira \& Nascimento, 2002).

Although chemical control is the only known means of controlling the pest effectively, it is not sustainable due to the necessity of frequent and regular applications, and a high cost (Siriwardena et al., 2015). Consequently, control that is associated with other measures, such as cultural control, botanical acaricides, and natural biological control can be adopted, in order to maintain this species at acceptable population levels (Moreira \& Nascimento, 2002). In addition, the control of this species is difficult because of its high mobility, microscopic 
size, and hidden lifestyle, making such an assessment time-consuming, tedious, and often inaccurate (Siriwardena et al., 2015).

There is a rapid growth in the screening of plant materials to find new bio-pesticides, as essential oil and its main components are effective in pest management; and besides, terpenoids have repellent properties and strong acaricidal activities (Ebadollahi et al., 2017; Sena-Filho et al., 2017; Wagan, Cai, \& Hua 2018). When considering the medicinal and biological importance of G. americana, this study has aimed to evaluate the chemical composition of essential oil from its leaves and its bioactivity (toxicity and repellency) against $A$. guerreronis.

\section{Method}

\subsection{Plant Material}

Fresh, mature and healthy leaves of G. americana were collected in the city of Nossa Senhora das Dores, Sergipe, Genipap Genebank (10 $29^{\prime} 30^{\prime \prime} \mathrm{S} ; 37^{\circ} 11^{\prime} 36^{\prime \prime} \mathrm{W} ; 204 \mathrm{~m}$ altitude) between the months of March and April 2016. The fresh leaves were cut and hydrodistilled immediately.

\subsection{Essential Oil Extraction}

The essential oil (EO) was extracted by hydrodistillation using a Clevenger-type apparatus. The fresh leaves (1 $\mathrm{kg}$ ) were distilled for $180 \mathrm{~min}$ using hexane as a solvent. The EO obtained was dried with powdered anhydrous sodium sulfate and stored at $4{ }^{\circ} \mathrm{C}$ in a sealed amber bottle before chemical analysis by gas chromatography coupled to mass spectrometry (GC/MS) and flame ionization detector (FID).

\subsection{GC-MS/FID Analysis}

The GC analyses were performed by using a GC-MS/FID (QP2010 Ultra, Shimadzu Corporation, Kyoto, Japan) that was equipped with an autosampler (AOC-20i, Shimadzu). The separations were accomplished using an Rtx ${ }^{\circledR}-5$ MS Restek fused silica capillary column (5\%-diphenyl-95\%-dimethyl polysiloxane) of $30 \mathrm{~m} \times 0.25 \mathrm{~mm}$ i.d., with a $0.25 \mu \mathrm{m}$ film thickness, at a constant helium (99.999\%) flow rate of $1.2 \mathrm{~mL} \mathrm{~min}{ }^{-1}$. An injection volume of $0.5 \mu \mathrm{L}$ was employed, with a split ratio of $1: 10$. The oven temperature program started at $60^{\circ} \mathrm{C}$, was held for $4 \mathrm{~min}$, then increased at a rate of $3{ }^{\circ} \mathrm{C} \mathrm{min}^{-1}$ to $300{ }^{\circ} \mathrm{C}$, followed by an increase of $20^{\circ} \mathrm{C} \mathrm{min}^{-1}$ to $280{ }^{\circ} \mathrm{C}$. The MS and FID data were simultaneously acquired by employing a Detector Splitting System; the split flow ratio was 5:1 (MS:FID). A $0.4 \mathrm{~m} \times 0.15 \mathrm{~mm}$ i.d. restrictor tube (capillary column) was used to connect the splitter to the MS detector; a $0.6 \mathrm{~m} \times 0.22 \mathrm{~mm}$ i.d. restrictor tube was used to connect the splitter to the FID detector. The MS data (total ion chromatogram, TIC) was acquired in full scan mode $(\mathrm{m} / \mathrm{z}$ of 40-550) at a scan rate of 0.3 scans $^{-1}$ using electron ionization at $70 \mathrm{eV}$. The injector temperature was set at $280{ }^{\circ} \mathrm{C}$ and the ion source temperature at $200^{\circ} \mathrm{C}$. The FID temperature was $300^{\circ} \mathrm{C}$, and the gas supplies for the FID were hydrogen, air, and helium, at flow rates of 30,300 , and $30 \mathrm{~mL} \mathrm{~min}{ }^{-1}$, respectively. The quantification of each constituent was estimated by FID peak-area normalization (\%). The compound concentrations were calculated from the GC peak areas and were arranged in the order of GC elution. The retention index (Adams, 2007) was obtained by co-injecting the oil sample with a C7-C30 linear hydrocarbon mixture; the identification was made based on a comparison of the retention index and the mass spectra with those in the literature (Adams, 2007; Linstron \& Mallard, 2005).

\subsection{Toxicity Bioassay}

The adult mites of A. guerreronis were collected from unsprayed coconut infested fruits in Empresa Brasileira de Pesquisa Agropecuaria (EMBRAPA) Tabuleiros Costeiros, Aracaju-SE $\left(10^{\circ} 57^{\prime} 03.3^{\prime \prime} \mathrm{S}, 37^{\circ} 03^{\prime} 07.4^{\prime \prime} \mathrm{W}\right)$. The coconut fruits were approximately 10 weeks old and they were collected for the construction of arenas from the same coconut plantation. The EO was sprayed through a Potter tower (Burkard, Rickmansworth, UK) onto discs $(1 \mathrm{~cm}$ diameter) that were prepared using the meristematic tissues of the new coconut fruits and then placed in Petri dishes (15 cm diameter, $2 \mathrm{~cm}$ deep) containing a mixture of $5 \%$ agar, $0.3 \%$ methylparaben $\left(\right.$ Nipagim $\left.^{\mathrm{TM}}\right)$ as a fungicide, and distilled water, as described by Oliveira et al. (2017).

The concentrations used were selected from initial concentration-mortality bioassays (Silva et al., 2013), ranging between the lower $(0 \%)$ and the higher $(100 \%)$ limits of mortality of the coconut mite. Increasing concentrations of $\mathrm{EO}\left(0.06,0.1,0.2,1.0,2.0,4.0\right.$, and $\left.5.0 \mathrm{mg} \mathrm{mL}^{-1}\right)$ were diluted in acetone and then the spraying was conducted at a pressure of $5 \mathrm{psi} / \mathrm{pol}^{2}$ with a $9.3 \mathrm{~mL}$ spray aliquot, which resulted in a residue of $1.38 \mathrm{mg} / \mathrm{cm}^{2}$, in line with the recommendations of the IOBC/WPRS (International Organization for Biological Control of Noxious Animals and Plants/West Palearctic Regional Section) (Hassan et al., 1994). Afterward, the sprayed discs were exposed to the environment for 30 minutes to dry. The arenas of the control treatment were sprayed with acetone and 20 adults were transferred with the help of a brush. Eight arenas (replicates) were used for each 
concentration of the EO tested and they were maintained at $24{ }^{\circ} \mathrm{C}$. The mite mortality was assessed after $24 \mathrm{~h}$ exposure and those mites that did not respond to the brush stimulus were considered dead.

\subsection{Repellency Bioassay}

The arenas were prepared as previously described. However, each arena consisted of a treated and an untreated area, and these were covered with two layers of adhesive tape during the spraying, as described by Teodoro et al., (2009). The arenas were sprayed with $\mathrm{LC}_{50}$ and $\mathrm{LC}_{90}$ solutions of the EO. After the drying of the solutions, a white glue point was placed in the center of the disc $\left(1.0 \times 1.0 \times 0.5 \mathrm{~cm}^{3}\right)$. Coconut mites were individually positioned under the white glue point and their positioning evaluations were performed after 1, 24, and 48 h. For each LC essential oil ( $\mathrm{LC}_{50}$ and $\left.\mathrm{LC}_{90}\right), 60$ replicates were performed.

\subsection{Data Analysis}

The lethal concentration and the confidence limits (CL) of G. americana EO were calculated by Probit analysis using SAS Software (SAS Institute, 2002). The frequency analyses used the Chi-square test and PROC FREQ SAS Software (SAS Institute 2008) was used to compare the percentages of mites choosing the sprayed and unsprayed disc halves.

\section{Results and Discussion}

\subsection{Chemical Composition}

The characterization of the chemical profiles via the GC-MS/FID analyses of EO of G. americana resulted in the identification of 42 compounds. The presence of short-chain fatty acids, aldehydes, monoterpenes, diterpenes, and sesquiterpenes was noticed (Table 1). The major compounds identified from the EO from the leaves were $(2 E, 4 E)$-decadienal $(6.01 \%),(E, E)$ - $\alpha$-farnesene $(5.10 \%)$, hexyl benzoate $(5.61 \%)$, pentadecanal $(11.55 \%)$, and linoleic acid (15.48\%). Chemodiversity has been reported, mainly being iridoids, followed by flavonoids, alkaloids, carboxylic acids, monoterpenes, and phytosterols isolated from the fruits and seeds of G. americana and they were tested for biological activities (Alves et al., 2017; Ramos-de-la-Peña et al., 2016; Souza et al., 2018). The presence of kaura-16-ene and hexadecanoic acid shed a light on the biosynthetic pathway and the enzyme expression during the growing period of the leaves. In addition, the presence of a diversity of a low and a medium-chain of reactive aldehyde was identified. These volatiles are toxic in a high concentration, and the presence of low and medium fatty acids was interesting when searching for rich lipids from the plants, since these compounds are toxic and are repellent to the coconut mite A. guerreronis (Silva et al., 2013; Teodoro et al., 2017). 
Table 1. Chemical composition (\%) identified in the essential oil extracted from the leaves of Genipa americana

\begin{tabular}{|c|c|c|c|c|}
\hline$t_{R}(\min )$ & Compounds & RI exp. & RI lit. & Composition \\
\hline 6.250 & (3Z)-hexen-1-ol & 840 & 850 & 0.66 \\
\hline 6.550 & Hexan-1-ol & 852 & 863 & 3.87 \\
\hline 9.615 & (2E)-heptenal & 947 & 947 & $\operatorname{tr}$ \\
\hline 11.080 & 2-pentylfuran & 982 & 984 & 0.19 \\
\hline 11.355 & Hexanoic acid & 989 & 967 & $\operatorname{tr}$ \\
\hline 13.635 & $(E)$ - $\beta$-ocimene & 1039 & 1044 & 4.67 \\
\hline 14.085 & $(2 E)$-octenal & 1049 & 1049 & 0.44 \\
\hline 14.820 & Octan-1-ol & 1065 & 1063 & 0.94 \\
\hline 16.095 & Linalool & 1092 & 1095 & 0.69 \\
\hline 16.280 & (6Z)-nonenal & 1096 & 1097 & 0.26 \\
\hline 19.015 & (2E)-nonenal & 1152 & 1157 & 0.27 \\
\hline 20.165 & Naphthalene & 1175 & 1178 & 0.65 \\
\hline 20.185 & Octanoic acid & 1176 & 1167 & $\operatorname{tr}$ \\
\hline 20.760 & Methyl salicylate & 1187 & 1190 & 0.31 \\
\hline 22.010 & $\beta$-cyclocitral & 1213 & 1217 & 0.30 \\
\hline 23.970 & $(2 E)$-decenal & 1254 & 1260 & 3.72 \\
\hline 26.560 & $(2 E, 4 E)$-decadienal & 1309 & 1315 & 6.01 \\
\hline 28.520 & Eugenol & 1351 & 1356 & 0.15 \\
\hline 28.725 & $\gamma$-nonalactone & 1355 & 1358 & 0.45 \\
\hline 29.340 & $\alpha$-copaene & 1368 & 1374 & 0.44 \\
\hline 29.705 & (E)- $\beta$-damascenone & 1376 & 1383 & 0.59 \\
\hline 31.050 & $(E)-\beta$-damascone & 1406 & 1413 & $\operatorname{tr}$ \\
\hline 31.325 & (E)-caryophyllene & 1412 & 1417 & 1.70 \\
\hline 32.660 & Geranylacetone & 1443 & 1453 & 0.38 \\
\hline 33.830 & Prenyl benzoate & 1469 & 1485 & 0.47 \\
\hline 34.220 & (E)- $\beta$-ionone & 1478 & 1487 & 0.97 \\
\hline 35.030 & $(E, E)$ - $\alpha$-farnesene & 1497 & 1505 & 5.10 \\
\hline 35.790 & $\delta$-cadinene & 1515 & 1522 & $\operatorname{tr}$ \\
\hline 37.450 & $(E)$-nerolidol & 1555 & 1561 & 0.35 \\
\hline 37.830 & (3Z)-hexenyl benzoate & 1564 & 1565 & 5.61 \\
\hline 38.035 & Hexyl benzoate & 1569 & 1579 & 1.20 \\
\hline 39.300 & Tetradecanal & 1600 & 1611 & 0.76 \\
\hline 41.825 & Tetradecan-1-ol & 1664 & 1671 & 0.20 \\
\hline 43.360 & Pentadecanal & 1704 & 1717 & 11.55 \\
\hline 45.370 & Benzyl benzoate & 1757 & 1759 & 0.15 \\
\hline 47.030 & Hexadecanal & 1802 & 1811 & 0.18 \\
\hline 48.110 & Hexahydrofarnesyl acetone & 1832 & 1845 & 0.93 \\
\hline 50.635 & Heptadecanal & 1903 & 1922 & 0.57 \\
\hline 50.850 & Methyl hexadecanoate & 1910 & 1921 & 0.25 \\
\hline 55.235 & Kaura-16-ene & 2041 & 2042 & 0.71 \\
\hline 56.655 & Methyl linolenate & 2084 & 2084 & 0.15 \\
\hline 58.245 & Linoleic acid & 2148 & 2132 & 15.48 \\
\hline
\end{tabular}

Note. RI exp., retention indices on the RTX-5MS column calculated according to van den Dool and Kratz (1963). RI lit., retention indices according to Adams (2007). tr, trace amounts of the compound were detected. Bold, major compounds.

\subsection{Toxicity to the Coconut Mite Aceria guerreronis}

The EO from G. americana exhibited acaricidal activities with $\mathrm{LC}_{50}$ and $\mathrm{LC}_{90}$ values of $0.41 \mathrm{mg} \mathrm{mL}^{-1}$ and 6.43 $\mathrm{mg} \mathrm{mL} \mathrm{m}^{-1}$, respectively (Table 2). Several studies have reported applications of natural products of plant origin as promising sources of acaricide, for integrated pest management in the replacement of conventional synthetic pesticides (Araújo et al., 2012; Miresmailli \& Isman, 2014). Crude vegetable oils have been characterized and tested against $A$. guerreronis, such as vegetable oil babassu, degummed soybean, and coconut oils (Oliveira et al., 2017). A further study conducted and evaluated the bioactivity of cottonseed oil to control A. guerreronis. 
Linoleic and oleic acids have been shown to be bioactive against pests, displaying toxic and repellent activities (Teodoro et al., 2017). Here, in this study, the synergistic action of terpenes and linoleic acid that was found in the leaves of G. americana may have contributed to the highly observed acaricidal activities.

Table 2. Lethal concentrations ( $\mathrm{LC}_{50}$ and $\left.\mathrm{LC}_{90}\right)\left(\mathrm{mg} \cdot \mathrm{mL}^{-1}\right.$ with $95 \%$ confidence interval in parentheses) of Genipa americana essential oil on the coconut mite Aceria guerreronis based on the concentration-mortality bioassays, after 24 hours of exposure

\begin{tabular}{|c|c|c|c|c|}
\hline Treatment & $\mathrm{LC}_{50}(95 \% \mathrm{CI})$ & $\mathrm{LC}_{90}(95 \% \mathrm{CI})$ & $\chi^{2}$ & $\mathrm{P}$ \\
\hline & 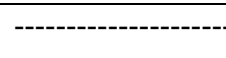 & $\mathrm{IL}$ & & \\
\hline EO & $0.41(0.34-0.49)$ & $6.43(4.59-9.82)$ & 0.949 & 0.713 \\
\hline
\end{tabular}

Note. Mean values obtained ( $\mathrm{n}=8$ replicates with 20 adult mites per replicate). The lethal concentrations $\left(\mathrm{LC}_{50}\right.$ and $\left.\mathrm{LC}_{90}\right)$ and the values $\left(\mathrm{mg} \mathrm{mL}^{-1}\right)$ were estimated using Probit analysis. $\mathrm{CI}=$ Confidence interval at $95 \%$ probability, $\chi^{2}=$ Chi-square, $\mathrm{P}=$ Probability $(\mathrm{p} \leq 0.05)$.

Acaricidal activities and the repellence of EO on phytophagous mites have been demonstrated (Araújo et al., 2012; Tak and Isman, 2017). Interestingly, in accordance with the results, the EO of Vitex gardneriana showed strong acaricidal activities on A. guerreronis (Sena-Filho et al., 2017). However, the $\mathrm{LC}_{50}$ estimated for the $\mathrm{EO}$ of $G$. americana $\left(0.41 \mathrm{mg} \mathrm{mL}^{-1}\right)$ was twice as low as the estimated $\mathrm{LC}_{50}$ for the $\mathrm{EO}$ of $V$. gardneriana $(0.85 \mathrm{mg}$ $\mathrm{mL}^{-1}$ ), therefore, being more toxic. Although the EO of G. americana is demonstrating its potential as a natural pesticide promisor for the control of A. guerreronis, it is still needed to be understood about its selectivity toward non-target organisms and natural enemies, mainly the predatory mites belonging to the family Phytoseiidae.

\subsection{Repellence of Essential Oil to Aceria guerreronis}

The $\mathrm{LC}_{50}$ and $\mathrm{LC}_{90}$ of the $\mathrm{EO}$ of $G$. americana were repellents to the coconut mites at all times of application of the compound (Fig 1). The effect was increased over 48 hours of evaluation. Thus, the sublethal effects of the oil were maintained throughout the experiment. Therefore, the substances present in the EO of G. americana can interfere with the behavior of $A$. guerreronis, because the arthropods are able to detect toxic substances and move away from the treated areas (Cordeiro et al., 2010). The cottonseed and palm oils have also presented repellent activities to A. guerreronis (Teodoro et al., 2017; Freitas et al., 2019). 

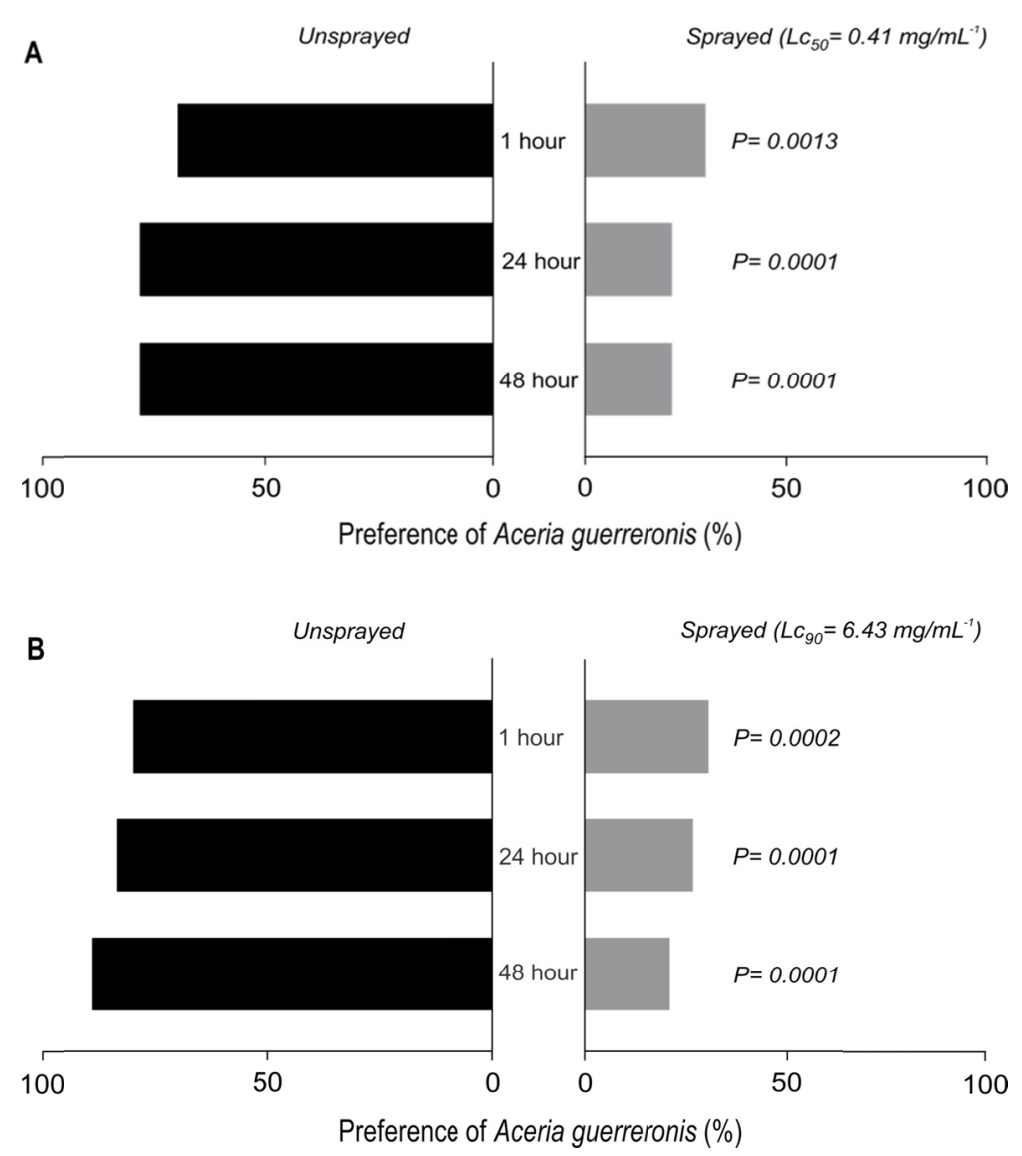

Figure 1. Repellency of $\mathrm{LC}_{50}(1 \mathrm{~A})$ and $\mathrm{LC}_{90}(1 \mathrm{~B})$ of the Genipa americana essential oil on the Aceria guerreronis coconut mite in percentages, after 1, 24, and 48 hours of spraying. Bar with the untreated area (black) and treated (grey)

All of this data tends to confirm that the bioactive compounds of EO seem to play an important role as an acaricide repellent. They may be effective in reducing the infestation of coconut mites, whose control is difficult because the colonies are protected by the bracts (Melo et al., 2014). Moreover, the G. americana extracts have biological properties that are associated with several molecules, such as steroids, iridoids, and monoterpenoids (Conceição et al., 2011; Ono et al., 2007; Codignoto et al., 2017). These results indicate that the EO from the leaves G. americana can be used to decrease the A. guerreronis infestation in coconut plantations. Further field studies, as well as information on the sublethal effects and selectivity, are required.

\section{Conclusion}

The EO of G. americana showed acaricidal effects after 24 hours of exposure, being also repellent to the coconut mite at the concentrations tested. It was possible to identify alcohols, aldehydes, monoterpenes, and sesquiterpenes in the chemical composition of the EO. It was reported for the first time of the presence of diterpenes in its composition. This EO has great potential for a natural acaricide development to contribute to future integrated management programs of pest mites.

\section{References}

Adams, R. P. (2007). Identification of Essential Oil Components by Gas Chromatography/Mass Spectrometry (4th ed., p. 804). Allured Publ. Corp., Carol Stream, IL.

Ajayi, O. E., Adedire, C. O., \& Lajide, L., (2012). Evaluation of partially purified fractions of crude extracts of the leaves of Morinda lucida (Benth.) and Datura stramonium (L.) for suppression of wood damage by subterranean termites. Journal of Agricultural Science, 4(5), 125-130. https://doi.org/10.5539/jas.v4n5p125

Alves, J. S. F., Medeiros, L. A., Fernandes-Pedrosa, M. F., Araújo, R. M., \& Zucolotto, S. M. (2017). Iridoids from leaf extract of Genipa americana. Revista Brasileira de Farmacognosia, 27(5), 641-644. https://doi.org/10.1016/j.bjp.2017.03.006 
Araújo, M. J. C., Câmara, C. A. G., Born, F. S., Moraes, M. M., \& Badji, C. A. (2012). Acaricidal activity and repellency of essential oil from Piper aduncum and its components against Tetranychus urticae. Experimental and Applied Acarology, 57(2), 139-155. https://doi.org/10.1007/s10493-012-9545-X

Bailão, E. F. L. C., Devilla, I. A., Conceição, E. C., \& Borges, L. L. (2015). Bioactive compounds found in Brazilian Cerrado fruits. International Journal of Molecular Sciences, 16(10), 23760-23783. https://doi.org/ 10.3390/ijms 161023760

Bentes, A. S., \& Mercadante, A. Z. (2014). Influence of the stage of ripeness on the composition of iridoids and phenolic compounds in genipap (Genipa americana L.). Journal of Agricultural and Food Chemistry, 62(44), 10800-10808. https://doi.org/10.1021/jf503378k

Codignoto, P. S. C., Araújo, S. B., Bastos, N. M., Fernandes, T. O., Barbosa, T. A. S., Igidio, C. E. D., ... Conceição, A. O. (2017). In vitro cytotoxicity and biological activities of Genipa americana (Rubiaceae) ethanolic extracts. African Journal of Microbiology Research, 11(9), 385-390. https://doi.org/10.5897/ ajmr2016.8418

Conceição, A. O., Rossi, M. H., Oliveira, F. F., Takser, L., \& Lafond, J. (2011). Genipa americana (Rubiaceae) fruit extract affects mitogen-activated protein kinase cell pathways in human trophoblast-derived BeWo cells: Implications for placental development. Journal of Medicinal Food, 14(5), 483-494. https://doi.org/ 10.1089/jmf.2009.0279

Cordeiro, E. M. G., Corrêa, A. S., Venzon, M., \& Guedes, R. N. C. (2010). Chemosphere Insecticide survival and behavioral avoidance in the lacewings Chrysoperla externa and Ceraeochrysa cubana. Chemosphere, 81(10), 1352-1357. https://doi.org/10.1016/j.chemosphere.2010.08.021

Ebadollahi1, A., Sendi, J. J., Maroufpoor, M., \& Rahimi-Nasrabadi, M. (2017). Acaricidal potentials of the terpene-rich essential oils of two Iranian eucalyptus species against Tetranychus urticae Koch. Journal of Oleo Science, 66(3), 307-314. https://doi.org/10.5650/jos.ess15258

Freitas, G. S., Sena-Filho, J. G., Araujo, W. V. S., Vieira, I. G., Oliveira, E. E., \& Teodoro, A. V. (2019). Acaricidal activity of the palm oil on Aceria guerreronis (Acari: Eriophyidae) and a nontarget predator. Journal of Entomological Science, 54(2), 60-68. https://doi.org/10.18474/JES18-67

Hassan, S. A., Bigler, F., Bogenschütz, F. H., Brown, J. U., Firth, S. I., Huang, P., ... Overmeer, W. P. J. (1994). Results of the second joint pesticide testing program by the IOBC/WPRS-Working group "Pesticides and beneficial arthropods. Entomophaga, 39, 107-119. https://doi.org/10.1007/978-1-4615-5791-3_3

Lawson-Balagbo, L. M., Gondim, M. G. C., Moraes, G. J., Hanna, R., \& Schausberger, P. (2008). Exploration of the acarine fauna on coconut palm in Brazil with emphasis on Aceria guerreronis (Acari: Eriophyidae) and its natural enemies. Bulletin of Entomological Research, 98(1), 83-96. https://doi.org/10.1017/S00074 85307005421

Lima, D. B., Melo, J. W. S., Gondim Jr., M. G. C., \& Moraes, G. J. (2012). Limitations of Neoseiulus baraki and Proctolaelaps bickleyi as control agents of Aceria guerreronis. Experimental and Applied Acarology, 56(3), 233-246. https://doi.org/10.1007/s10493-012-9515-3

Linstrom, P. J., \& Mallard, W. G. (2005). NIST Chemistry Webbook (NIST Standard Reference Database Number 69). Gaithersburg: National Institute of Standards and Technology.

Melo, J. W. S., Lima, D. B., Pallini, A., Oliveira, J. E. M., \& Gondim, M. G. C. (2011). Olfactory response of predatory mites to vegetative and reproductive parts of coconut palm infested by Aceria guerreronis. Experimental and Applied Acarology, 55(2), 191-202. https://doi.org/10.1007/s10493-011-9465-1

Melo, J. W. S., Lima, D. B., Sabelis, M. W., Pallini, A., \& Gondim, M. G. C. (2014). Host finding behavior of the coconut mite Aceria guerreronis. Experimental and Applied Acarology, 64(4), 445-454. https://doi.org/ 10.1007/s10493-014-9834-7

Miresmailli, S., \& Isman, M. B. (2014). Botanical insecticides inspired by plant-herbivore chemical interactions. Trends in Plant Science, 19(1), 29-35. https://doi.org/10.1016/j.tplants.2013.10.002

Moreira, J. O. T., \& Nascimento, A. R. P. (2002). Avaliação da eficiência de acaricidas isolados e em mistura no controle do ácaro-da-necrose-do-coqueiro Aceria guerreronis Keifer, 1965 (Prostigmata: Eriophyidae) no Vale do São Francisco. Revista Brasileira de Fruticultura, 24(1), 72-76. https://doi.org/10.1590/ S0100-29452002000100016 
Navia, D., Gondim Jr., M. G. C., Aratchige, N. S., \& Moraes, G. J. M. (2013). A review of the status of the coconut mite, Aceria guerreronis (Acari: Eriophyidae), a major tropical mite pest. Experimental and Applied Acarology, 59(1-2), 67-94. https://doi.org/10.1007/s10493-012-9634-х

Oliveira, N. N. F. C., Galvão, S. A., Amaral, E. A., Santos, A. W. O., Sena-Filho, J. G., Oliveira, E. E., \& Teodoro, A. V. (2017). Toxicity of vegetable oils to the coconut mite Aceria guerreronis and selectivity against the predator. Experimental and Applied Acarology, 72(1), 23-34. https://doi.org/10.1007/ s10493-017-0134-x

Ono, M., Ishimatsu, N., Masuoka, C., Yoshimitsu, H., Tsuchihashi, R., Okawa, M., ... Nohara, T. (2007). Three new monoterpenoids from the fruit of Genipa americana. Chemical and Pharmaceutical Bulletin (Tokyo), 55(4), 632-634. https://doi.org/10.1248/cpb.55.632

Ramos-de-la-Peña, A. M., Renard, C. M. G. C., Montañez, J., Reyes-Vega, M. D. L. L., \& Contreras-Esquivel, J. C. (2016). A review through recovery, purification, and identification of genipin. Phytochemistry Reviews, 15(1), 37-49. https://doi.org/10.1007/s11101-014-9383-z

Sá, F. P., Souza, F. V. D., Silva, A. V. C., \& Lédo, A. S. (2015). Encapsulamento, crioproteção e desidratação na capacidade regenerativa de ápices caulinares de Genipa americana. Ciência Rural, 45(11), 1939-1945. https://doi.org/10.1590/0103-8478cr20140579

Sena-Filho, J. G., Barreto, I. C., Soares-Filho, A. O., Nogueira, P. C. L., Teodoro, A. V., Silva, A. V. C., ... Duringer, J. M. (2017). Volatile metabolomic composition of Vitex species: Chemodiversity insights and acaricidal activity. Frontiers in Plant Science, 8, 1-9. https://doi.org/10.3389/fpls.2017.01931

Silva, A. C. B., Teodoro, A. V., Oliveria, E. E., Rêgo, A. S., \& Silva, R. R. (2013). Toxicity of neem oil to the cassava green mite Mononychellus tanajoa (Bondar) (Acari: Tetranychidae). Chilean Journal of Agricultural Research, 73(3), 315-319. https://doi.org/10.4067/S0718-58392013000300016

Silva, L. A., Resende, O., Virgolino, Z. Z., Bessa, J. F. V., Morais, W. A., \& Vidal, V. M. (2015). Cinética de secagem e difusividade efetiva em folhas de jenipapo (Genipa americana L.). Revista Brasileira de Plantas Medicinais, 17(4), 953-963. https://doi.org/10.1590/1983-084X/14_106

Siriwardena, P. H. A. P., Fernando, L. C. P., \& Peiris, T. S. G. (2005). A new method to estimate the population size of coconut mite, Aceria guerreronis, on a coconut. Experimental and Applied Acarology, 37(1-2), 123-129. https://doi.org/10.1007/s10493-005-7125-z

Souza, I. V., Gondim, M. G. C., Ramos, A. L. R., Santos, E. A., Ferraz, M. I. F., \& Oliveira, A. R. (2012). Population dynamics of Aceria guerreronis (Acari: Eriophyidae) and other mites associated with coconut fruits in Una, state of Bahia, northeastern Brazil. Experimental and Applied Acarology, 58(3), 221-233. https://doi.org/10.1007/s10493-012-9576-3

Souza, R. O. D. S., Souza, P. L., Menezes, R. R. P. P. B., Sampaio, T. L., Tessarolo, L. D., Silva, F. C. O., ... Martins, A. M. C. (2018). Trypanocidal activity of polysaccharide extract from Genipa americana leaves. Journal of Ethnopharmacology, 210, 311-317. https://doi.org/10.1016/j.jep.2017.08.042

Tak, J. H., \& Isman, B. M. (2017). Acaricidal and repellent activity of plant essential oil-derived terpenes and the effect of binary mixtures against Tetranychus urticae Koch (Acari: tetranychidae). Industrial Crops and Products, 108, 786-792. https://doi.org/10.1016/j.indcrop.2017.08.003

Teodoro, A. V., Pallini, A., \& Oliveira, C. (2009). Sub-lethal effects of fenbutatin oxide on prey location by the predatory mite Iphiseiodes zuluagai (Acari: Phytoseiidae). Experimental and Applied Acarology, 47(4), 293-299. https://doi.org/10.1007/s10493-008-9219-x

Teodoro, A. V., Silva, M. J. S., Sena-Filho, J. G., Oliveira, E. E., Galvão, A. S., \& Silva, S. S. (2017). Bioactivity of cottonseed oil against the coconut mite Aceria guerreronis (Acari: Eriophyidae) and side effects on Typhlodromus ornatus (Acari: Phytoseiidae). Systematic and Applied Acarology, 22(7), 1037-1047. https://doi.org/10.11158/saa.22.7.11

van den Dool, H., \& Kratz, P. D. (1963). A generalization of the retention index system including linear temperature programmed gas-liquid partition chromatography. Journal of Chromatography, 11, 463-471.

Wagan, T. A., Cai, W., \& Hua, H. (2018). Repellency, toxicity, and antioviposition of essential oil of Gardenia jasminoides and its four major chemical components against whiteflies and mites. Scientific Reports, 8(1), 9375. https://doi.org/10.1038/s41598-018-27366-5 


\section{Copyrights}

Copyright for this article is retained by the author(s), with first publication rights granted to the journal.

This is an open-access article distributed under the terms and conditions of the Creative Commons Attribution license (http://creativecommons.org/licenses/by/4.0/). 